\title{
A Review On Various Analytical Techniques For Determining REEs
}

\author{
Cemile Özcan \\ Kirklareli University, Istitute of Science, Chemistry Department, Kirklareli, Turkey \\ cemilebal.ozcan@klu.edu.tr \\ Received date: 6.03.2021, Accepted date: 01.07.2021
}

\begin{abstract}
Due to the transition from traditional energy sources to clean energy in recent years, it is stated that there will be a continuous increase in the need for REEs worldwide in the coming years owing to their especial physical and chemical properties. The principal sources of REEs are the minerals bastnazite, monazite, and xenotime, etc.. Rare earths have peculiar, unique properties and become essential in many high-tech applications. Therefore, the REEs is used for applications such as improvement of industrial. It is worth highlighting that the separation of rare earth can be both complex and challenging owing to similar properties which are shared to produce high quality and better quantity of REEs. In industrial production, complex ores containing rare earth elements are concentrated by physical ore beneficiation processes. For this, the processes proposed in this work possesses aguide on green chemistry, solvent extraction, membran filtration, adsorption of recovering REEs through stepwise extraction and enrichment technique. This review, attempts to provide notable information on the separation and purification efforts to date for the recovery of REEs.
\end{abstract}

Keywords: Rare-earth elements, adsorption, green chemistry, extraction

\section{REE'lerin Belirlenmesine Yönelik Çeşitli Analitik Teknikler Üzerine Bir Derleme}

\section{$\ddot{O} z$}

Son yıllarda geleneksel enerji kaynaklarından temiz enerjiye geçiş nedeniyle, özellikle fiziksel ve kimyasal özelliklerinden dolayı NTE'lere olan ihtiyacın dünya genelinde önümüzdeki yıllarda sürekli bir artış olacağ1 belirtilmektedir. Nadir toprak elementlerinin temel kaynakları, bastnazit, monazit ve ksenotim vb. mineralleridir. Nadir toprak elementleri (NTE) kendine özgü, benzersiz özelliklere sahiptir ve birçok yüksek teknoloji uygulamasında gerekli hale gelmektedir. $\mathrm{Bu}$ nedenle, NTE'ler endüstriyel iyileştirme gibi uygulamalar için kullanılmaktadır. Endüstriyel üretimde, nadir toprak elementi içeren kompleks cevherler fiziksel cevher zenginleştirme prosesleriyle deriştirirler. Yüksek kalitede ve daha iyi miktarda REE üretmek için paylaşılan benzer özellikler nedeniyle nadir toprak ayrıştırmasının hem karmaşık hem de zor olabileceğini vurgulamakta fayda var. Bunun için, bu çalışmada önerilen süreçler, yeşil kimya, çözücü ekstraksiyonu, membran filtrasyonu, ardışık ekstraksiyon ve zenginleştirme, adsorpsiyon tekniği yoluyla NTE'nin geri kazanımı üzerine bir kılavuza sahiptir. Bu derleme, NTE'lerin geri kazanımı için şimdiye kadar yapılan ayırma ve saflaştırma çalışmaları hakkında dikkate değer bilgi sağlamaya çalışmaktadır.

Anahtar kelimeler: Nadir toprak elementleri, adsorpsiyon, yeşil kimya, ekstraksiyon

\section{INTRODUCTION}

The Rare Earth Elements (REEs) according to the International Union of Pure and Applied Chemistry (IUPAC) include in a sum of 17 elements which containing 14 natural and 1 artificial element. The REEs are known as the lanthanides (La) starting from the mass number of 57 up to lutetium $(\mathrm{Lu})$ with mass number of 71 plus yttrium (Y) and scandium (Sc), and also have similar the chemical/physical properties, due to magnetic and optical properties (Henderson, 1984; Suli et al., 2017). Moreover, the relative abundance tendency of REEs is regular and conforms to the Oddo-Harkins rule. According to the Oddo-Harkins rule, elements with the double atomic numbers are more ample than elements with the single atomic numbers, and the abundance of elements decreases along the lanthanide series (Zhou 
et al., 2017). REEs in the world tend to be found in the same ore deposits owing to their similar properties. In addition, REEs are classified as the heavy earth elements (Y, Gd, Tb, Dy, Ho, Er, Tm, $\mathrm{Yb}$ and $\mathrm{Lu}$ ) and the light earth elements ( $\mathrm{Sc}, \mathrm{La}, \mathrm{Ce}$, Pr, Nd, Pm, Sm and Eu) (Quinn et al., 2017; Romero-Freire et al., 2018; Kürüm and Özdemir, 2020). Today, REEs are indispensable for highly sophisticated technology and defense applications. Some ores (apatite, euxenite, gadolinite, xenotime, allanite, fluorite, barite, bastnasite, perovskite, sphene, and zircon etc.) can be classified as a valuable source of REEs (Kul et al., 2008; Karadağ et al., 2009; Akıska et al., 2019).

Therefore, REEs take part in industrial request for incremented, due to a significant function in many disciplines, such as medical, renewable energy, super conductors, permanent magnet, imaging agents, glass additives, fertilizer and feed additives, cosmetics, ceramics, carbon arc lamps, alloys, catalysts, defense, electronics and nuclear technologies (Nasab et al., 2011; Ault et al., 2015; Fisher and Kara, 2016; Gao et al., 2017; Suli et al., 2017; Balaram, 2019). Such uses, constitute an important part of the use of REEs. Therefore, it can be predicted that the new century will be a period in which international conflicts of interest gradually intensify in terms of especially the REEs, due to the increase in the consumption of the REEs together with the increase in production. About $80 \%$ of the world rare earth mineral production (as oxide) is bastnazite, $4 \%$ is monazite and xenotime, the remainder is produced from other sources (Suli et al., 2017). Additionaly, the REEs are also being produced from apatite, brannerite, oxenite, gadolinite, loparite and uraninite. Allanite, apatite and other phosphorous resources, eudialite, fergusonite, fluorenite, parisite, perovskite, pyrochlor, zircon and several other naturally occurring rare earth-bearing minerals are also considered as potential REE resources (Suli et al., 2017). REEs are relatively plentiful in the Earth's crust, on the other hand, they are usually occur in concentrated and economically valorable mineral deposits (Jaroni et al., 2019). World reserves of REEs are132 million tonnes (Balaram 2019), but REEs reserves potentially in Turkey are approximately 50 million tonnes (Öztürk et al., 2019). The Çanaklı, Kızılcaören, Karacaören, Kuluncak, Divriği, Keban, Kemiklitepe, Kızıldağ,
Seydişehir, Şarkikaraağaç, Aksu, Doğankuzu and Sofular in Turkey, contain important potentially sources of REEs mineralisation (Deady et al., 2016; Y1ldız et al., 2016; Kopar et al., 2018; Akıska et al., 2019; Öztürk et al., 2019). Moreover, Agostini et al. (2019) investigated by some trace element contents, in particular the LILE and the REE of the youngest volcanic rocks in the region (Elazı $\breve{g}$, Karakoçan, Tunceli, Mazgirt, Pertek). In addition, authors were stated that high field ftrength elements (HFSE) such as $\mathrm{Zr}$ and $\mathrm{Nb}$ - and REE, do not show clear correlation with $\mathrm{SiO}_{2}$, whereas $\mathrm{Th}$ shows a welldefined positive correlation according to geochemical data. Furthermore, the provinces and the districts where REEs are located in Turkey are given in Table 1.

Table 1: Provinces and districts located of REEs in Turkey

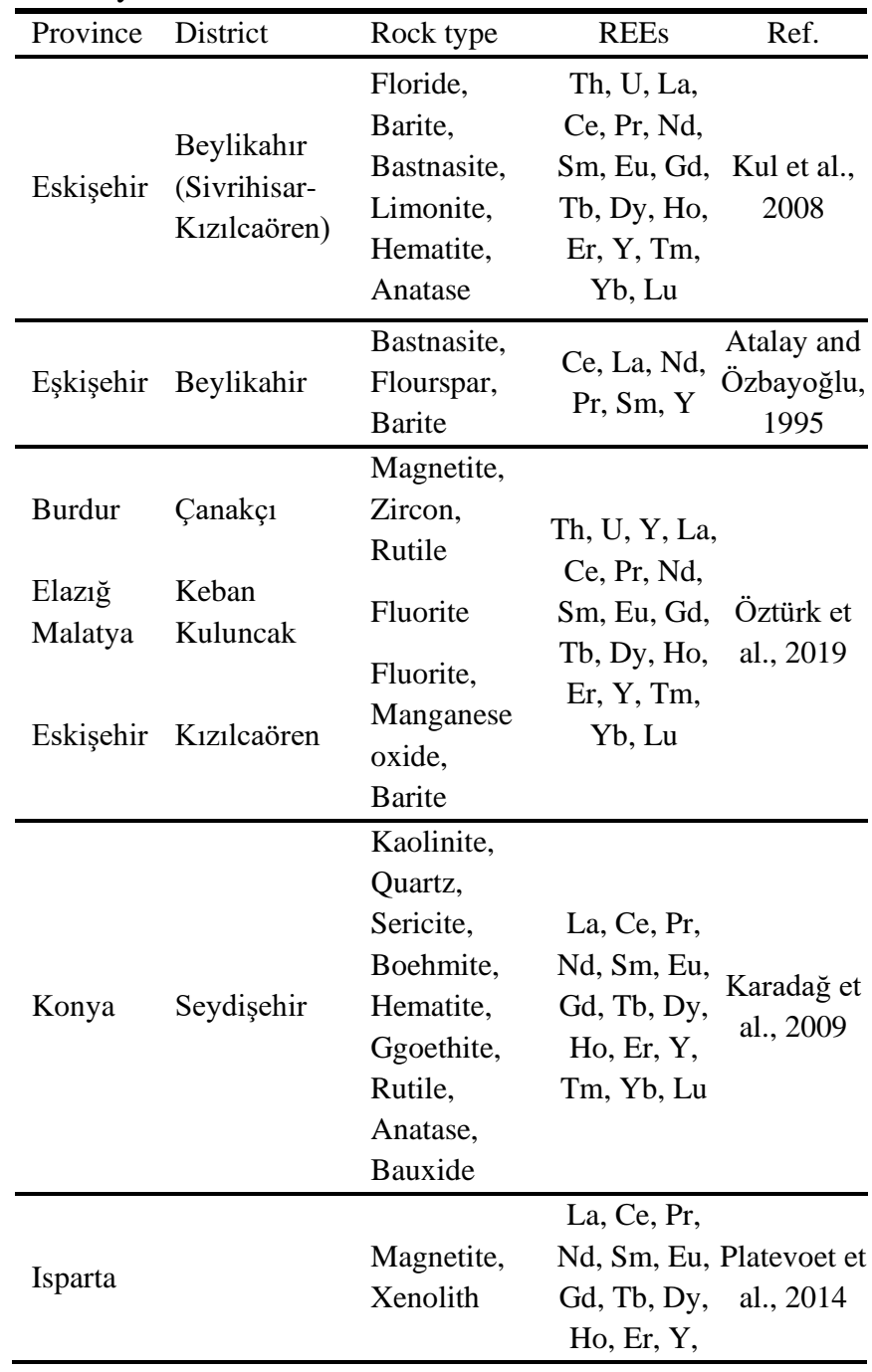




\begin{tabular}{|c|c|c|c|c|}
\hline & & \multicolumn{3}{|c|}{$\mathrm{Tm}, \mathrm{Yb}, \mathrm{Lu}$} \\
\hline Eşkişehir & Kızılcaören & $\begin{array}{l}\text { Barite, } \\
\text { Fluorite }\end{array}$ & $\mathrm{La}, \mathrm{Ce}, \mathrm{Pr}$, & \\
\hline $\begin{array}{l}\text { Malatya } \\
\text { İsparta }\end{array}$ & $\begin{array}{l}\text { Sofular } \\
\text { Çanaklı }\end{array}$ & Thorite, & Gd, Tb, Dy, & \\
\hline Konya & $\begin{array}{l}\text { Mortaş- } \\
\text { Doğankuzu }\end{array}$ & $\begin{array}{l}\text { Britholite, } \\
\text { Bastnasite }\end{array}$ & $\begin{array}{l}\text { Ho, Er, Y, } \\
\text { Tm, Yb, Lu, }\end{array}$ & $\begin{array}{c}\text { Ak1ska et } \\
\text { al., } 2019\end{array}$ \\
\hline Eskişehir & Sivrihisar & & & \\
\hline $\begin{array}{l}\text { Uşak } \\
\text { Manisa }\end{array}$ & $\begin{array}{l}\text { Fakı11-Meşe } \\
\text { Salihli- } \\
\text { Köprübaș1 }\end{array}$ & $\begin{array}{l}\text { Sedimentary } \\
\text { rocks }\end{array}$ & $\mathrm{U}$ & \\
\hline
\end{tabular}

The option of extractants and aqueous solution conditions for recovery of REEs is affected both by cost considerations and technical specifications, such as selectivity. Therefore, for recovery and separation in individual and collective purification of REEs have been studied extensively by using various techniques such as precipitation, gravity separation, flotation, leaching, solvent extraction (liquid-liquid extraction, dispersive liquid-liquid micro-extraction and solidified floating drop microextraction). Moreover, solid phase extraction (SPE), adsorption, dry digestion, ion exchange chromatography and biosorption are available in addition to magnetic separation and electrostatic separation. The supporting practices which used in the physical ore extraction are usually such as activated charcoal, silica gel, activated alumina, zeolites, membranes and synthetic polymeric resins (Nasab et al., 2011; Ashour et al., 2016; Zhang et al., 2016b; Amaral et al., 2017; Hidayah, and Abidin, 2017; Quinn et al., 2017; Rivera et al., 2018; Cao et al., 2019; Ponou et al., 2019; Gupta et al., 2019; Chen et al., 2019; Léniz-Pizarro et al., 2021). Very strong acids carry out in the solvent extraction during the extraction process of REEs and then these chemicals leach out into the environment and be transported through water bodies and cause the acidification of aquatic environments. In order to avoid wasting too much solvent, the green chemistry applications with less solvent and chemicals should be preffered. Thus, the solutions and the nanocomposite materials (bio/adsorbent) used in purification will be used repeatedly, contributing to the economy.

An example flowsheet of the liquid-liquid extraction procedure used for the separation of REEs is shown in Figure 1. In this process, the number of chemicals in solvent extraction can greatly negatively affect the environmental. It is also necessary to research and find suitable methods to reduce these effects (such as less chemical use); such as solid phase extraction (SPE), solid phase micro extraction (SPME), supercritical fluid extraction (SFE), and ultasonic extraction. Therefore, among these, SPE is an extremely preferred procedure owing to its advantages, such as simple operation, low cost, and high enrichment factor (Zhang et al., 2016a; Chen et al., 2019). Optimal parameters for the element to be enriched by the SPE are physicochemical properties of adsorbent, solution $\mathrm{pH}$ and charge, adsorption characteristics, competing species, temperature and contact time (of solution and sample). As well as, the $\mathrm{pH}$ of a solution plays a significant role in the adsorption process as it strongly affect the speciation of metal ions in the solution and the surface polarity of an adsorbent material. Therefore, SPE and similar techniques have been one of the commonly used methods in pretreatment of ore samples for the extraction of REEs. Because, with SPE of REEs eliminates most of the disadvantages of LLE such as the nascency of weak contacts between extractant and wanted elements. Because SPE's is simple to put into practice, generally high preconcentration factor to be achieveed, quick separation, and can be effortlessly/directly integrated into automated analytical techniques. Thus, probably with the growing application of green chemistry (because it reduces pollution), throughout the twenty one century, provide the global demand for REEs will increase continuously (Zhou et al., 2017). For the application of green chemistry in the recovery of REEs is given an example in Figure 2 (Callura et al., 2018).

In addition to the extraction of REEs, in the determination techniques are also very important. The investigation and determination of REEs have been used in various analytical techniques. Examples include, inductively coupled plasmaoptical emission spectrometry (ICP-OES) (Waqar at al., 2009; Karadaş, and Kara, 2014), inductively coupled plasma-mass spectrometry (ICP-MS) (Fu et al., 2007; Karadaş et al., 2011; Monazam at al., 2018), atomic spectrometry (Biju, and Prasada Rao, 2005), potentiometry (Ali, and Mohamed, 2015), ultraviolet-visible spectrophotometry (UV-Vis) (Gok, et al., 2007; Ganjali, et al., 2009; Vizioli et al., 2009), neutron activation analysis (NAA) (El-Taher, 
2007), X-ray fluorescence (XRF) (Simandl et al., 2013), isotopic dilution mass spectrometry (Greaves et al., 1989).

Meanwhile, Ashour et al., (2016) investigated that adsorption and desorption attitude for the rare earth (RE) metal ions $\left(\mathrm{La}^{3+}, \mathrm{Nd}^{3+}, \mathrm{Gd}^{3+}\right.$ and $\left.\mathrm{Y}^{3+}\right)$ with magnetic iron oxide nanoparticles functionalized by L-cysteine. In study investigated a SPE method the iron oxide nanoparticles plated with L-cysteine (Cys- $\left.\mathrm{Fe}_{3} \mathrm{O}_{4} \mathrm{NPs}\right)$ materials was carried out for the extraction and selective separation of target RE ions, for the evaluation of each method parameters in the batch adsorption tests were established for example burdening capacity, adsorption kinetics, thermodynamics parameters and effect of $\mathrm{pH}$. Thus, in study with $\mathrm{Cys}-\mathrm{Fe}_{3} \mathrm{O}_{4} \mathrm{NPs}$, at pH 6 within $15 \mathrm{~min}$, and the adsorbent penchant for metal ions has found to be in order of $\mathrm{Nd}^{3+}>\mathrm{La}^{3+}>\mathrm{Gd}^{3+}>\mathrm{Y}^{3+}$ ions. They have executed high removal yield 96.7, 99.3, 96.5 and $87 \%$ for $\mathrm{La}^{3+}$, $\mathrm{Nd}^{3+}, \mathrm{Gd}^{3+}$ and $\mathrm{Y}^{3+}$ ions, respectively, by ICP-OES used to determine the concentrations of metal ions. Therefore, reuptake-recovery of REEs can be achieved with magnetic nanoparticles for separation processes.
Rao et al., (2010) were investigated and reported the remobilisation of REEs $(\mathrm{Y}, \mathrm{La}, \mathrm{Ce}, \mathrm{Pr}$, $\mathrm{Nd}, \mathrm{Sm}, \mathrm{Eu}, \mathrm{Gd}, \mathrm{Tb}, \mathrm{Dy}, \mathrm{Ho}, \mathrm{Er}, \mathrm{Tm}, \mathrm{Yb}, \mathrm{Lu})$ in four different soil types by harnessing the optimised the by the Commission of the European Communities Bureau of Reference (BCR) sequential extraction procedure. The researchers in this study were caried a comparability of partial extraction conclusions using the $\mathrm{BCR}$ procedure (unbuffered salt solutions $0.1 \mathrm{M} \mathrm{NaNO}_{3}, 0.01 \mathrm{M} \mathrm{CaCl}_{2}, 1 \mathrm{M}$ $\mathrm{NH}_{4} \mathrm{NO}_{3}$; complexing agents $0.005 \mathrm{M}$ DTPA and $0.05 \mathrm{M}$ EDTA; acid solutions $0.43 \mathrm{M} \mathrm{CH}_{3} \mathrm{COOH}$ and $1 \mathrm{M} \mathrm{HCl}$ ). REEs have been extracted by sequential and single extraction and analyzed by using ICP-MS. Furthermore, researchers have shown that total extractable contents and the association of REEs in various types of four soil samples by the BCR sequential extraction can be used successfully. In the experimental study, approximately over $24 \mathrm{~h}$ with $1 \mathrm{M} \mathrm{HCl}$, same amount were found to released under the partial extraction of REEs.

In literature for determination of REEs in various samples by different analytical techniques were applied. Samples and details of these techniques were shown that Table 2. 


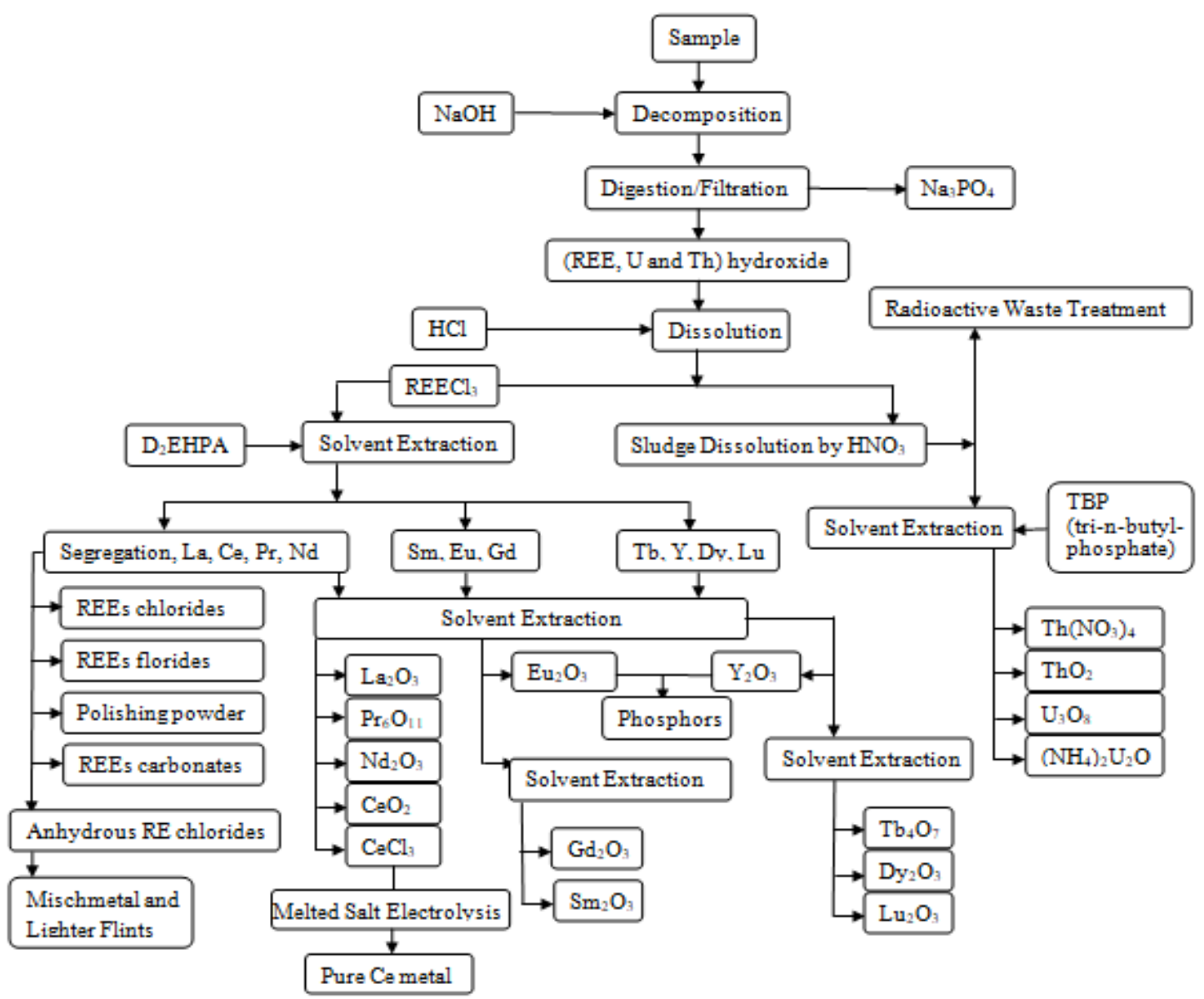

Figure 1. The segregation of REEs by solvent extraction (Xie, et al., 2014; Zang, et al., 1982).

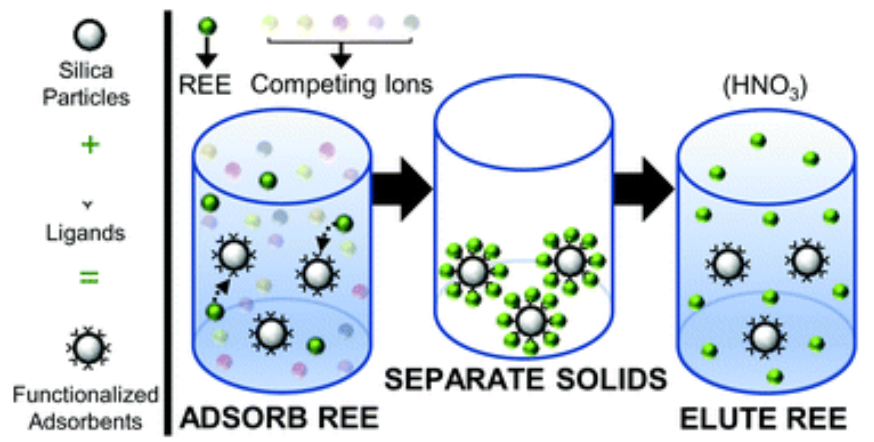

Figure 2. The application of green chemistry in the recovery of REEs by SPE (Callura et al., 2018)

Table 2. Application of instrumental analytical techniques for the determination of REES

\begin{tabular}{|l|c|c|c|c|c|c|c|c|c|}
\hline Samples & pH & Adsorbent & REE & $\begin{array}{c}\text { Extraction } \\
\text { Type }\end{array}$ & $\begin{array}{c}\text { Analytical } \\
\text { Technique }\end{array}$ & $\begin{array}{c}\text { Enrichment } \\
\text { or } \\
\text { Separation } \\
\text { Factor }\end{array}$ & $\begin{array}{c}\text { LOD } \\
(\mathbf{n g} / \text { L) } \\
\text { and } \\
\text { RSD\% }\end{array}$ & $\begin{array}{c}\text { Recovery } \\
(\%)\end{array}$ & $\begin{array}{c}\text { Ref. } \\
\text { Natural }\end{array}$ \\
\hline
\end{tabular}




\begin{tabular}{|c|c|c|c|c|c|c|c|c|c|}
\hline waters & & $\begin{array}{c}\text { AG5OW- } \\
\text { X8 }\end{array}$ & \begin{tabular}{|}
$\mathrm{Nd}$, \\
$\mathrm{Sm}$, \\
$\mathrm{Eu}$, \\
$\mathrm{Gd}$, \\
$\mathrm{Dy}, \mathrm{Er}$, \\
$\mathrm{Yb}, \mathrm{Lu}$
\end{tabular} & & $\begin{array}{l}\text { dilution } \\
\text { mass } \\
\text { spectrometr } \\
\text { y }\end{array}$ & & $\begin{array}{l}\text { pmol } \\
\text { and } 4\end{array}$ & & $\begin{array}{l}\text { et al., } \\
1989\end{array}$ \\
\hline $\begin{array}{l}\text { Synthetic } \\
\text { samples }\end{array}$ & \begin{tabular}{|l|l}
7.5 \\
\end{tabular} & $\begin{array}{l}\text { XAD-4, } \\
\text { XAD-7 }\end{array}$ & $\begin{array}{l}\mathrm{Ce}, \mathrm{La} \\
\text { and } \mathrm{Pr}\end{array}$ & SPE & $\begin{array}{l}\text { XRF and } \\
\text { UV-Vis }\end{array}$ & 500 & $\begin{array}{c}0.36- \\
1.07 \\
\text { and }\end{array}$ & 100 & $\begin{array}{c}\text { Masi and } \\
\text { Olsina } \\
1993\end{array}$ \\
\hline $\begin{array}{l}\text { Granite } \\
\text { rocks }\end{array}$ & - & - & \begin{tabular}{|c|}
$\mathrm{Yb}$, \\
$\mathrm{Sm}$, \\
$\mathrm{Nd}$, \\
$\mathrm{Lu}, \mathrm{La}$, \\
$\mathrm{Eu}, \mathrm{Ce}$
\end{tabular} & - & NAA & - & $\begin{array}{c}0.01- \\
3.8 \text { and }\end{array}$ & - & $\begin{array}{c}\text { El- } \\
\text { Taher, } \\
2007\end{array}$ \\
\hline Soil & $\begin{array}{c}6.79 \\
- \\
7.98\end{array}$ & - & REEs & $\begin{array}{l}\text { single and } \\
\text { sequential } \\
\text { extraction }\end{array}$ & ICP-MS & - & $\begin{array}{l}0.02< \\
\text { and - }\end{array}$ & $0.80-109$ & \begin{tabular}{|c|} 
Rao et \\
al., 2010
\end{tabular} \\
\hline Zarigan Ore & $2-4$ & $\begin{array}{c}\text { D2EHPA, } \\
\text { Cyanex302, } \\
\text { Cyanex272 }\end{array}$ & \begin{tabular}{|c|}
$\mathrm{La}, \mathrm{Y}$, \\
$\mathrm{Th}$ and \\
$\mathrm{Ce}$
\end{tabular} & $\begin{array}{c}\text { Solvent } \\
\text { extraction }\end{array}$ & ICP-OES & 2.4 & - & $\begin{array}{c}22-92.7 \\
\text { for } \mathrm{La} \text {, } \\
28-95 \text { for } \\
\mathrm{Ce}\end{array}$ & $\begin{array}{l}\text { Nasab et } \\
\text { al., } 2011\end{array}$ \\
\hline Ore & - & - & $\begin{array}{c}\mathrm{Nd}, \mathrm{Pr}, \\
\mathrm{Ce}, \mathrm{La}, \\
\mathrm{Y}\end{array}$ & - & XRF & - & $\begin{array}{l}5-10 \\
\text { and } \\
1.4- \\
16.3\end{array}$ & - & $\begin{array}{l}\text { Simandl } \\
\text { et al., } \\
2013\end{array}$ \\
\hline $\begin{array}{l}\text { Industrial } \\
\text { application } \\
\text { (organic and } \\
\text { aqueous } \\
\text { phases) }\end{array}$ & $\begin{array}{c}0.5- \\
2.5\end{array}$ & $\begin{array}{l}\text { EHEHPA, } \\
\text { Cyanex 572, } \\
\text { Cyanex 272 }\end{array}$ & $\begin{array}{c}\mathrm{Ce}, \mathrm{Pr}, \\
\mathrm{Nd}, \\
\mathrm{Sm}, \\
\mathrm{Tb}, \\
\mathrm{Dy}, \\
\mathrm{Ho}, \mathrm{Er}, \\
\mathrm{Yb}, \mathrm{Lu} \\
\text { and } \mathrm{Y}\end{array}$ & \begin{tabular}{|c} 
Solvent \\
extraction \\
(quaternary \\
ammonium \\
phosphonate \\
ionic liquid)
\end{tabular} & $\begin{array}{c}\text { ICP-MS } \\
\text { and ICP- } \\
\text { OES }\end{array}$ & $1.5-11.7$ & - & $20-78$ & $\begin{array}{l}\text { Quinn et } \\
\text { al., } 2015\end{array}$ \\
\hline $\begin{array}{l}\text { Deep } \\
\text { groundwater }\end{array}$ & 3 & MWCNT & \begin{tabular}{|c}
$\mathrm{Ce}, \mathrm{Pr}$, \\
$\mathrm{Nd}$, \\
$\mathrm{Sm}$, \\
$\mathrm{Eu}$, \\
$\mathrm{Gd}$, \\
$\mathrm{Tb}$, \\
$\mathrm{Dy}$, \\
$\mathrm{Ho}, \mathrm{Er}$, \\
$\mathrm{Tm}$, \\
$\mathrm{Yb}$, \\
$\mathrm{Lu}, \mathrm{La}$
\end{tabular} & $\begin{array}{l}\text { Solid-Phase } \\
\text { Extraction }\end{array}$ & $\mathrm{ICP}-\mathrm{MS}$ & 25 & \begin{tabular}{|c}
$0.31-$ \\
1.2 and \\
$<5$
\end{tabular} & $\begin{array}{l}97.4- \\
101.3\end{array}$ & $\begin{array}{c}\text { Zhang et } \\
\text { al., } \\
2016 \mathrm{a}\end{array}$ \\
\hline $\begin{array}{l}\text { East Lake } \\
\text { Yangtze } \\
\end{array}$ & 6 & $\begin{array}{l}\text { Saussurea } \\
\text { tridactyla }\end{array}$ & $\begin{array}{l}\mathrm{Y}, \mathrm{La}, \\
\mathrm{Ce}, \mathrm{Pr},\end{array}$ & $\begin{array}{c}\text { Solvent } \\
\text { Extraction }\end{array}$ & ICP-OES & 10 & $\begin{array}{c}0.72- \\
86.9 \\
\end{array}$ & \begin{tabular}{|l|}
$80.7-120$ \\
$74.9-125$ \\
\end{tabular} & $\begin{array}{c}\begin{array}{c}\text { Zhang et } \\
\text { al., }\end{array} \\
\end{array}$ \\
\hline
\end{tabular}




\begin{tabular}{|c|c|c|c|c|c|c|c|c|c|}
\hline River & & \multirow{2}{*}{$\begin{array}{l}\text { Sch-Bip } \\
\text { (STSB) }\end{array}$} & \multirow[b]{2}{*}{$\begin{array}{c}\mathrm{Nd}, \\
\mathrm{Sm}, \\
\mathrm{Eu}, \\
\mathrm{Gd}, \\
\mathrm{Tb}, \\
\mathrm{Dy}, \\
\mathrm{Ho}, \mathrm{Er}, \\
\mathrm{Tm}, \\
\mathrm{Yb} \text { and } \\
\mathrm{Lu}\end{array}$} & & & & \multirow{2}{*}{$\begin{array}{c}\text { and } \\
2.4-8.9\end{array}$} & & \multirow[t]{2}{*}{$2016 b$} \\
\hline Rain water & & & & & & & & $84.3-110$ & \\
\hline $\begin{array}{l}\text { Industrial } \\
\text { application } \\
\text { (organic and } \\
\text { aqueous } \\
\text { phases) }\end{array}$ & $0.9-5$ & EHEHPA & $\begin{array}{c}\mathrm{Ce}, \mathrm{Pr}, \\
\mathrm{Nd}, \\
\mathrm{Sm}, \\
\mathrm{Tb}, \\
\mathrm{Dy}, \\
\mathrm{Ho}, \mathrm{Er}, \\
\mathrm{Yb}, \mathrm{Lu} \\
\text { and Y }\end{array}$ & $\begin{array}{c}\text { Solvent } \\
\text { Extraction } \\
\text { (bifunctiona } \\
1 \text { ionic } \\
\text { liquid) }\end{array}$ & $\begin{array}{l}\text { ICP-OES } \\
\text { and UV-Vis }\end{array}$ & $1.6-14.6$ & - & $27-87$ & $\begin{array}{l}\text { Quinn et } \\
\text { al., } 2017\end{array}$ \\
\hline Sediment & \begin{tabular}{|l|}
5.38 \\
-6.16
\end{tabular} & $\begin{array}{c}\mathrm{HNO}: \mathrm{HCl} \\
(7: 3 \mathrm{v} / \mathrm{v}) \\
\text { and } \\
\text { Microorgani } \\
\text { sm materials }\end{array}$ & Total & $\begin{array}{l}\text { Partial and } \\
\text { Liquid } \\
\text { Extraction }\end{array}$ & ICP-MS & $1-3$ & - & $\begin{array}{c}\text { for BCR- } \\
667 \text { was } \\
54.6 \pm \\
12 \%\end{array}$ & $\begin{array}{l}\text { Romero- } \\
\text { Freire et } \\
\text { al., } 2018\end{array}$ \\
\hline $\begin{array}{l}\text { Aqueous } \\
\text { solution }\end{array}$ & - & $\begin{array}{l}\text { Dowex } \\
50 W-X 8\end{array}$ & $\begin{array}{l}\text { Ce3+, } \\
\text { Sm3+, } \\
\text { Yb3+ }\end{array}$ & SPE & ICP-MS & - & - & - & $\begin{array}{c}\text { Monaza } \\
\text { m et al., } \\
2018\end{array}$ \\
\hline $\begin{array}{l}\text { Chemically } \\
\text { complex } \\
\text { synthetic- } \\
\text { and real } \\
\text { brine } \\
\text { solutions }\end{array}$ & $\begin{array}{l}7 \text { and } \\
2\end{array}$ & $\begin{array}{c}\text { Silika } \\
\text { (PAA and } \\
\text { DTPADA } \\
\text { as ligand) }\end{array}$ & $\begin{array}{c}\mathrm{Nd}, \\
\mathrm{Gd}, \mathrm{Ho}\end{array}$ & SPE & ICP-MS & 200 & $1 \mathrm{ppb}$ & 90 & $\begin{array}{l}\text { Callura } \\
\text { et al., } \\
2018\end{array}$ \\
\hline $\begin{array}{l}\begin{array}{l}\text { Water } \\
\text { samples }\end{array} \\
\text { Tea leaves } \\
\text { Human hair }\end{array}$ & $7-9$ & $\begin{array}{l}\text { Magnetic } \\
\mathrm{ZnFe} 2 \mathrm{O} 4 \\
\text { nanotubes }\end{array}$ & $\begin{array}{l}\text { La, Pr, } \\
\text { Eu, } \\
\text { Gd, } \\
\text { Ho, Yb }\end{array}$ & \begin{tabular}{|l} 
Dispersive \\
Micro \\
Solid-Phase \\
Extraction
\end{tabular} & ICP-MS & 120 & $\begin{array}{c}0.01- \\
1.2 \text { and } \\
2.5-6.3\end{array}$ & 93-107 & $\begin{array}{l}\text { Chen et } \\
\text { al., } 2019\end{array}$ \\
\hline $\begin{array}{l}\text { Aqueous } \\
\text { solutions }\end{array}$ & 2.7 & $\begin{array}{l}\text { polyaromati } \\
\text { c amide } \\
\text { membrane }\end{array}$ & $\begin{array}{l}\mathrm{La} 3+, \\
\mathrm{Nd} 3+\end{array}$ & SPE & ICP-MS & - & - & 99.3-99.8 & $\begin{array}{l}\text { Léniz- } \\
\text { Pizarro } \\
\text { et al., } \\
2021\end{array}$ \\
\hline
\end{tabular}

The determination of REEs (Ce, Dy, Er, Eu, Gd, Ho, La, Lu, Nd, Pr, Sc, Sm, Tb, Th, Tm, Y, and $\mathrm{Yb}$ ) in geological samples, fertilizer, and agricultural gypsum samples were found using ICP-OES by Amaral et al. (2017). The most plentiful REEs in the
Earth's layer in this study are $\mathrm{Ce}, \mathrm{La}, \mathrm{Nd}$, and $\mathrm{Y}(31-$ $66 \mu \mathrm{g} / \mathrm{g})$, while $\mathrm{Tm}$ and $\mathrm{Lu}(0.5-0.8 \mu \mathrm{g} / \mathrm{g})$ has been reported in more decreased concentrations.

According to Takahashi et al. (2005), the extraction of REE reached an equilibrium in $10 \mathrm{~min}$ 
at $\mathrm{pH} 4$ with $0.39 \mathrm{~g} / \mathrm{L}$ concentration of strain and an increase in the concentration of microorganism materials (Bacillus subtilis) had increased the enrichment of REE on microorganism. They stated that adsorption efficiency of REEs was reduced by the increasing of $\mathrm{pH}$ and churning time. Therefore, this researchers suggested that the interaction between microorganism and REEs determine the accuracy of the microbial materials because the binding sites on the bacterial cell wall are phosphate and carboxyl groups.

A study conducted by Huang et al (2017) have revealed elective recovery of REEs ( $\mathrm{Y}, \mathrm{La}, \mathrm{Ce}, \mathrm{Pr}$, $\mathrm{Nd}, \mathrm{Sm}, \mathrm{Eu}$ ) from ion-adsorption from REE ores by stepwise extraction with 2-ethylhexylphosphonic mono-2-ethylhexyl ester (HEH(EHP)) and di-(2ethylhexyl) phosphoric acid (HDEHP). They have been evolved a novel environmentally friendly solvent extraction method for the segregation and enrichment of REEs. Moreover, with this study was reduced the amount of nitrogen in the form of ammonia in waste waters and increased the low recovery efficiency of the present extraction process for REEs. The partitioning and low concentration of REEs in the aqueous solution have been determined using ICP-Atomic Emission Spectrometry (ICPAES). The total recovery efficiency was realized for REEs has been found $>99 \%$.

Detailing by Reka et al. (2021), the diatomaceous earth (involved $\mathrm{SiO}_{2}, \mathrm{Al}_{2} \mathrm{O}_{3}, \mathrm{Fe}_{2} \mathrm{O}_{3}$, $\mathrm{CaO}, \mathrm{MgO}, \mathrm{K}_{2} \mathrm{O}, \mathrm{Na}_{2} \mathrm{O}$, and $\mathrm{P}_{2} \mathrm{O}_{5}$ ) collected from the Mariovo area, North Macedonia were by ICPMS with the classical chemical analysis digestion, and thoriumn amount was found as $7,9 \mathrm{mg} / \mathrm{kg}$.

Researchers will also contribute to green chemistry with the new adsorbents or membrane filters they will produce using the ionic radius of REEs (Karadağ et al., 2009; Karadaş, and Kara, 2014; Léniz-Pizarro et al., 2021). A specific potential application of membranes is the recovery of REEs from aqueous solutions. Ionic radius is very important in the membrane filtration techniques. Because ionic radius can be mostly used for a good separation-purification in the membrane filtration. In order to contribute to the separation-purification studies of REEs with membrane filters, the data with ionic charge and ion diameters are given in Table 3. (Berke, 2014).

Table 3. Ionic charges and ion radiuses of REEs

\begin{tabular}{lcl}
\hline REE & $\begin{array}{c}\text { Ionic charge in } \\
\text { the solution }\end{array}$ & Ionic radius $\left(\mathrm{A}^{\circ}\right)$ \\
\hline $\mathrm{La}$ & $3+$ & 1.04 \\
$\mathrm{Ce}$ & $3+, 4+$ & $1.02-0.92$ \\
$\mathrm{Pr}$ & $3+, 4+$ & 1.00 \\
$\mathrm{Nd}$ & $3+$ & 0.99 \\
$\mathrm{Pm}$ & $3+$ & - \\
$\mathrm{Sm}$ & $2+, 3+$ & $1.11-0.96$ \\
$\mathrm{Eu}$ & $2+, 3+$ & $1.06-0.96$ \\
$\mathrm{Gd}$ & $3+$ & 0.94 \\
$\mathrm{~Tb}$ & $3+, 4+$ & 0.92 \\
$\mathrm{Dy}$ & $3+$ & 0.91 \\
$\mathrm{Ho}$ & $3+$ & 0.89 \\
$\mathrm{Er}$ & $3+$ & 0.87 \\
$\mathrm{Tm}$ & $3+$ & 0.86 \\
$\mathrm{Yb}$ & $2+, 3+$ & $0.93-0.85$ \\
$\mathrm{Lu}$ & $3+$ & 0.84 \\
$\mathrm{Y}$ & $3+$ & 0.88 \\
$\mathrm{Th}$ & $4+$ & 0.99 \\
\hline
\end{tabular}

Ultimately, efforts to use less chemicals combined with the use of different adsorbents or membranes to improve the selectivity and capacity for specific ions could greatly increase the capacity and selectivity of REEs adsorption. Moreover, solvents used in recovery should not be harmful to the bio/adsorbent material, they should be cheaper, the environmentally friendly and effective.

\section{CONCLUSION}

REEs have peculiar and unique properties, and become necessary in very high-tech applications. For recovery and separation both the determination techniques and the extraction methods of REEs are also very important. The method of ICP-OES and ICP-MS were presented multicomponent ability and selectivity that was adaptable with precise REE determination in complex materials of environmental samples for example geological and agricultural samples. Moreover, for recovery and separation in individual and collective purification of REEs have been studied extensively by using various techniques such as precipitation, gravity separation, flotation, leaching, solvent extraction, SPE, adsorption, biosorption, dry digestion and ion exchange chromatography. The REEs are found in ores, like apatite, euxenite, gadolinite, xenotime, allanite, fluorite, barite, bastnasite, perovskite, 
sphene, and zircon. So long as now lot of work has been implement on the heavy metals but little work has been accomplished on the separation and purification of REEs. This review will contribute to the literature to purify and separate REEs. Moreover, it is known that consumption of REEs in developed countries will increase in the coming years in parallel with the production of REEs. Furthermore, the deposits of REEs in the rewiev are involved the provinces and the districts of Turkey, well thought out, carefully crafted and will have formed a longterm strategy in the near future.

\section{CONFLICT OF INTEREST}

The Author report no conflict of interest relevant to this article.

\section{RESEARCH AND PUBLICATION ETHICS STATEMENT}

The author declares that this study complies with research and publication ethics.

\section{REFERENCES}

Agostini, S., Savaş̧̧ı, M.Y., di Giuseppe, P., di Stefano, F., Karaoğlu, Ö., Lustrino, M., Manetti, P., Ersoy, Y., Kürüm, S., Öztüfekçi Önal, A., 2019. Neogene volcanism in Elazığ-Tunceli area (eastern Anatolia): geochronological and petrological constraints. Italian Journal of Geosciences, 138:435-455.

Akıska, E., Karakas, Z., Öztürk C., 2019. Uranium, Thorium and Rare Earth Element Deposits of Turkey. In: Pirajno F., Ünlü T., Dönmez C., Sahin M. (eds) Mineral Resources of Turkey. Modern Approaches in Solid Earth Sciences (Springer, Cham.), 16:655-679.

Ali, T.A., Mohamed, G.G., 2015. Potentiometric determination of $\mathrm{La}(\mathrm{III})$ in polluted water samples using modified screen-printed electrode by selfassembled mercapto compound on silver nanoparticles. Sensors\&Actuators, B, 216:542-550.

Amaral, C.D.B., Machado, R.C., Barros, J.A.V.A., Virgilio, A., Schiavo, D., Nogueira, A.R.A., Nóbrega, J.A., 2017. Determination of rare earth elements in geological and agricultural samples by ICP-OES. Spectroscopy, 32(10):32-36.

Ashour, R.M., Abdel-Magied, A.F., Abdel-khalek, A.A., Helaly, O.S., Ali, M.M. 2016. Preparation and characterization of magnetic iron oxide nanoparticles functionalized by 1-cysteine: Adsorption and desorption behavior for rare earth metal ions. Journal of Environmental Chemical Engineering, 4(3):3114-3121.
Atalay, Ü., Özbayoğlu, G., 1995. Benefication of Beylikahir Complex Rare Earth Deposit of Turkey. Fizykochemiczne Problemy Mineralurgii, 29:19-29.

Ault, T., Krahn, S., Croff, A., 2015. Radiological Impacts and Regulation of Rare Earth Elements in NonNuclear Energy Production. Eneries, 8:2066-2081.

Berke, M.S., 2014. Eskişehir-Beylikahır Kompleks Cevheri Lantanit Grubu Elementlerin Toryum ve Uranyumdan Metalurjik Proseslerle Ekstraksiyonu, Yüksek Lisans Tezi, İstanbul Teknik Üniversitesi, Fen Bilimleri Enstitüsü, İstanbul.

Biju, V.M., Prasada Rao T., 2005. FAAS determination of selected rare earth elements coupled with multielement solid phase extractive preconcentration. Chemia Analityczna, 50 (2005) 935-944.

Chen, S., Yan, J., Li, J., Lu, D., 2019. Magnetic $\mathrm{ZnFe}_{2} \mathrm{O}_{4}$ nanotubes for dispersive micro solid-phase extraction of trace rare earth elements prior to their determination by ICP-MS. Microchimica Acta, 186(4):1-7.

Callura, J.C., Perkins, K.M., Noack, C.W., Washburn, N.R., Dzombak, D.A., Karamalidis, A.K. 2018. Selective adsorption of rare earth elements onto functionalized silica particles. Green Chemistry, 20(7):1515-1526.

Deady, E., Goodenough K., Lacinska A., Hardy L., Shaw R., 2016. Rare earth element placer deposits and alkaline volcanics: a case study from Aksu Diamas, Çanakl1, Turkey. Applied Earth Science, 125:79-80.

El-Taher, A., 2007. Rare-earth elements in Egyptian granite by instrumental neutron activation analysis. Applied Radiation and Isotopes, 65(4):458-464.

Fu, Q., Yang, L., Wang, Q., 2007. On-line preconcentration with a novel alkyl phosphinic acid extraction resin coupled with inductively coupled plasma mass spectrometry for determination of trace rare earth elements in seawater. Talanta, 72:12481254.

Ganjali, M.R., Zare-Dorabei, R., Norouzi, P., 2009. Design and construction of a novel optical sensor for determination of trace amounts of dysprosium ion. Sensors\&Actuators, B, 143:233-238.

Gok, C., Seyhan, S., Merdivan, M., Yurdakoc, M., 2007. Separation and preconcentration of $\mathrm{La}^{3+}, \mathrm{Ce}^{3+}$ and $\mathrm{Y}^{3+}$ using calix[4]resorcinarene impregnated on polymeric support. Microchimica Acta, 157:13-19.

Greaves, M.J., Elderfield, H., Klinkhammer, G.P., 1989. Determination of the rare earth elements in natural waters by isotope-dilution mass spectrometry. Analytica Chimica Acta, 218:265-280.

Gupta, N.K., Gupta, A., Ramteke, P., Sahoo, H., Sengupta, A., 2018. Biosorption-a green method for the preconcentration of rare earth elements (REEs) from waste solutions: A review. Journal of Molecular Liquids, 274:148-164. 
Henderson, P., 1984. General geochemical properties and abundances of the rare earth elements. Developments in Geochemistry, 1-32.

Hidayah, N.N., Abidin, S.Z., 2017. The evolution of mineral processing in extraction of rare earth elements using solid-liquid extraction over liquidliquid extraction: A review. Minerals Engineering, $112,103-113$.

Huang, X., Dong, J., Wang, L., Feng, Z., Xue, Q., Meng, X., 2017. Selective recovery of rare earth elements from ion-adsorption rare earth element ores by stepwise extraction with HEH(EHP) and HDEHP. Green Chemistry, 19(5):1345-1352.

Jaroni, M.S., Friedrich, B., Letmathe, P., 2019. Economical feasibility of rare earth mining outside China. Minerals, 9:576-594.

Karadağ, M.M., Küpeli, Ş., Arık, F., Ayhan, A., Zedef, V., Döyen, A., 2009. Rare earth element (REE) geochemistry and genetic implications of the Mortaş-bauxite deposit (Seydişehir/Konya Southern Turkey). Chemie der Erde-Geochemistry, 69:143159.

Karadaş, C., Kara, D., 2014. Determination of rare earth elements by solid phase extraction using chemically modified Amberlite XAD-4 resin and inductively coupled plasma-optical emission spectrometry. Water, Air, Soil Pollution, 225:1-10.

Karadaş, C., Kara, D., Fisher, A., 2011. Determination of rare earth elements in seawater by inductively coupled plasma mass spectrometry with off-line column preconcentration using 2,6-diacetylpyridine functionalized Amber lite XAD-4. Analytica Chimica Acta, 689:184-189.

Kopar, İ., Çelik, M.A., Bayram, H., 2018. Kapadokya Volkanik Provensi'ndeki volkan rölyefinin antropojenik degradasyonu üzerine bir analiz. Türk Coğrafya Dergisi, 71:37-46.

Kul, M., Topkaya, Y., Karakaya, İ., 2008. Rare earth double sulfates from pre-concentrated bastnasite. Hydrometallurgy, 93(3-4):129-135.

Kürüm, S., Özdemir, N., 2020. Erzerum Bölgesinde Palandöken Volkanik Kayaçlarının Petrografik ve Jeokimyasal Özellikleri, Doğu Anadolu, Türkiye. International Journal of Pure and Applied Sciences, 6(2):42-60.

Léniz-Pizarro, F., Liu, C., Colburn, A., Escobar, I.C., Bhattacharyya, D., 2021. Positively charged nanofiltration membrane synthesis, transport models, and lanthanides separation. Journal of Membrane Science, 620: 118973.

Masi, A.N., Olsina, R.A., 1993. Preconcentration and determination of $\mathrm{Ce}$, $\mathrm{La}$ and $\mathrm{Pr}$ by X-ray fluorescence analysis, using Amberlite XAD resins loaded with 8-Quinolinol and 2-(2-(5 chloropyridylazo)-5-dimethylamino)-phenol.

Talanta, 40(6), 931-934.

Monazam, E., Siriwardane, R., Miller, D., McIntyre, D., 2018. Rate analysis of sorption of $\mathrm{Ce}^{3+}, \mathrm{Sm}^{3+}$, and $\mathrm{Y}^{\mathrm{b} 3+}$ ions from aqueous solution using Dowex 50W$\mathrm{X} 8$ as a sorbent in a continuous flow reactor. Journal of Rare Earths, 36(6):648-655.

Nasab, M.E., Sam, A., Milani, S.A., 2011. Determination of optimum process conditions for the separation of thorium and rare earth elements by solvent extraction. Hydrometallurgy, 106(3-4):141-147.

Öztürk, H., Hanilçi, N., Altuncu, S., Kasapçı, C., 2019. Rare earth element (REE) resources of Turkey: An overview of their characteristics and origin. Bulletin of the Mineral Research and Exploration, 159:129143.

Suli, L.M., Ibrahim, W.H.W., Aziz, B.A., Deraman, M.R., Ismail, N.A., 2017. A Review of Rare Earth Mineral Processing Technology. Chemical Engineering Research Bulletin, 19:20-35.

Platevoet, B., Elitok, Ö., Guillou, H., Bardintzeff, J.M., Yagmurlu, F., Nomade, S., Poisson, A., Deniel, C., Özgür, N. 2014. Petrology of Quaternary volcanic rocks and related plutonic xenoliths from Gölcük volcano, Isparta Angle, Turkey: Origin and evolution of the high-K alkaline series. Journal of Asian Earth Sciences, 92:53-76.

Quinn, J.E., Soldenhoff, K.H., Stevens, G.W., Lengkeek, N.A., 2015. Solvent extraction of rare earth elements using phosphonic/phosphinic acid mixtures. Hydrometallurgy, 157:298-305.

Quinn, J.E., Soldenhoff, K.H., Stevens, G.W., 2017. Solvent extraction of rare earth elements using a bifunctional ionic liquid. Part 2: Separation of rare earth elements. Hydrometallurgy, 169:621-628.

Rao, C.R.M., Sahuquillo, A., Lopez-Sanchez, J.F., 2010. Comparison of single and sequential extraction procedures for the study of rare earth elements remobilisation in different types of soils. Analytica Chimica Acta, 662(2):128-136.

Reka, A.A., Pavlovski, B., Fazlija, E., Berisha, A., Pacarizi, M., Daghmehchi, M., Sacalis, C., Jovanovski, G., Makreski, P., Oral, A., 2021. Diatomaceous Earth: Characterization, thermal modification, and application. Open Chemistry, 19:451-461.

Romero-Freire, A., Minguez, L., Pelletier, M., Cayer, A., Caillet, C., Devin, S., Giamberini, L., 2018. Assessment of baseline ecotoxicity of sediments from a prospective mining area enriched in light rare earth elements. Science of The Total Environment, 612:831-839.

Simandl, G.J., Stone, R.S., Paradis, S., Fajber, R., Reid, H.M., Grattan, K., 2013. An assessment of a handheld X-ray fluorescence instrument for use in exploration and development with an emphasis on 
REEs and related specialty metals. Mineralium Deposita, 49(8):999-1012.

Takahashi, Y., Châtellier, X., Hattori, K.H., Kato, K., Fortin, D., 2005. Adsorption of rare earth elements onto bacteria cell walls and its implication for REE sorption onto natural microbial mats. Chemical Geology, 219:53-67.

Vizioli, N., Gil, R., Martinez, L.D., Silva, M.F., 2009. On-line solid phase extraction CZE for the simultaneous determination of lanthanum and gadolinium at picogram per liter levels. Electrophoresis, 30:2681-2687.

Yıldı, A., Gürel, A., Dursun, Y.G., 2016. Physicochemical properties and uses of Karacaören area (Nevşehir) diatomite. Bulletin of The Mineral Research and Exploration, 152:165-180.

Waqar, F., Jan, S., Mohammad, B., Hakim, M., Alam, S., Yawar, W., 2009. Preconcentration of rare earth elements in seawater with chelating resin having fluorinated beta-diketone immobilized on styrene divinyl benzene for their determination by ICP-OES. Journal of the Chinese Chemical Society, 56:335340

Xie, F., Zhang, T.A., Dreisinger, D., Doyle, F., 2014. A critical review on solvent extraction of rare earths from aqueous solutions. Minerals Engineering, $56: 10-28$.

Zang, Z.B., Yi King, L.K., Chu, K., Cheng, W.W., Cheng, W.W., 1982. Rare earth industry in China. Hydrometallurgy, 9(2):205-210.

Zhang, J., Wang, X., Dong, Y., Xu, Z., Li, G., 2016a. Solid Phase Extraction of Rare Earth Elements in Deep Groundwater With Multi-wall Carbon Nanotubes asAdsorbent for the Determination by Inductively Coupled Plasma MassSpectrometry. Atomic Spectroscopy, 37(1):1-6.

Zhang, Q., He, M., Chen, B., Hu, B., 2016b. Preparation, characterization and application of Saussurea tridactyla Sch-Bip as green adsorbents for preconcentration of rare earth elements in environmental water samples. Spectrochimica Acta Part B: Atomic Spectroscopy, 121:1-10.

Zhou, B., Li, Z., Chen, C., 2017. Global potential of rare earth resources and rare earth demand from clean technologies. Minerals, 7(11):203-14. 